Ignatio Ponsti J. B. J, S. 30. 811. 1948.

\begin{tabular}{|c|c|c|c|c|c|c|}
\hline 木, 浦川 & 外 & & & 科 & 12巻, & 11 号 \\
\hline 本 & 日 & 整 & 会 & 誌 & 27 巻. & 1 号 \\
\hline 沢 & 整 & 形 & 外 & 科 & 5 巻. & 2 号 \\
\hline 淵 & 外 & & & 科 & 18巻. & 7 만 \\
\hline 木 & 整 & 形 & 外 & 科 & 10巻. & \\
\hline 地 & 臨床 & & & & & \\
\hline
\end{tabular}

鹿大整形荒木崇文 この症例は，鹿児島で行われた骨腫瘍懇談会で出し たものですが，その後，経過を追うことが出来ました ので追加する.

患者は 9 才男, 左脛骨エオジン好性肉芽腫, 搔把, 骨移植しましたが，キブス固定中転倒，同部の亀裂骨 折を発生, 6 力月間で完全治療しました。

\title{
侏儒症と先天性骨系統疾患
}

\begin{tabular}{|c|c|c|c|}
\hline $\begin{array}{c}\text { 鳥取大学医学部整形外科教室 } \\
\text { (主任; 西尾騜人教授) }\end{array}$ & 花 & 北 & 良 \\
\hline & 池 & 内 & \\
\hline $\begin{array}{l}\text { 鳥取大学医学部石原内科教室 } \\
\text { (任; 石原国 教授) }\end{array}$ & 原 & 田 & 義 \\
\hline
\end{tabular}

\section{The Dwarfisms due to Congenital General Bone Diseases}

\author{
by
}

\section{Yoshimi Hanakita, Takeshi Ikeuchi}

(Dept. of Orthopedic Surgery, Faculty of Medicine, Tottori Univ.)

and

\section{Yoshimichi Harada}

(Dept. of 2nd Internal Medicine, Faculty of Medicine, Tottori Univ.)

侏儒症は色々な原因によつて発生し，其の分類法に ついても数多くの記載があるが, 我々が昭和 32 年以降 経験した侏懦性のうち所謂, 骨系統突患に基くものは 35 例で，之を便宜上，Howorth 飞従い原因別に分類 すると第 1 表の如くである，本報告は此の中，主な先 天性骨系統疾患について骨変化を中心に再吟味をを行 つたあのである.

\section{Achondroplasia 及び Osteochondrodystrophy}

表でも明かな如く，侏儒症の原因となる骨系統疾患 の大半は広義の Chondrodystrophy によつて占めら れるが, 従来「ヒョンドロ」と総称された疾患も今日 では Achondroplasia と Osteochondrodystrophy の二つに大別され，更に後者からは其の特殊型として Morquio 病や Gargoylism 等が新しく独立疾患とし

$$
\text { 第 } 1 \text { 表 }
$$

侏儒症の原因別分類

I. 骨疾患飞基くもの

A. The chondrodystrophy 1. Achondroplasia
2. Osteochondrodystrophy

3. Lipochondrodystrophy

4. Morquio's disease

5. Dyschondroplasia

6. Osteopetrosis

7. Disease of the spine

B. Osteogenesis imperfecta

C. Rickets ( atypical )

II. 多少共骨病変を伴う全身疾患
A. Constitutional (Mongolism etc.)
B. Nutritional Privation
C. Chronic infections
D. Alcaptonuria

III. 内臓殊飞内分泌機能障碍

A. Visceral

B. Endocrine

1. Hypothyroidism

2. Sexual precocity with early epiphyseal fusion

3. Hypopituitarism

4. Hypoinsulinism

5. Mixed type

IV. Primordial Dwarfism 
て分類される傾向にある. 之等の症例を観察して先づ 感ずる事は, Osteochondrodystrophy は Achondroplasia の亜型とみなされている位に臨床像, レ線像 が酷似している上に相互間に多くの移行型があり, 従 来報告された症例に症状をあてはめようとしても仲々 完全には一致するととが少いという事である．最近 Achondroplasia と Osteochondrodystrophy の鑑別 点として, 発病年令, 四肢の均衡の有無, 外観, レ線 所見などが挙げられるが, 先づ発病年令にしても Achondroplasia の軽症例では生后数年たつてから, その異常に気付く事ああり得るし, 又レ線像に於てあ 後述の如く両者とあに多様性の変化を呈するために確 実な鑑別点とはなし難く, 従つて強いて両者を区別し ようとすれば, 結局次の様な外観上の特徵を参考とす る外にない様に思われる。

Osteochondrodystrophy の特徵; (1), 躯幹が短 く四肢は比較的長い (2), 頭蓋は躯幹に比し変化が軽 い(3), 顔貌は Gargoylism を除き正常 (4), 龟背, 側彎, 鳩胸及び漏斗胸の存在 (5), 上肢の変化は少く 下肢は上肢に比し変化が高度.

之等の特徵によつて両者を大ま加区別し，以下主 として Achondroplasia 12 例の臨床像を 再検討する と

1）先づ監幹に比し四肢が著しく短いという Disproportion は全例にみられるが, 上肢化於方各品部の Proportion は症例によつて種々である, 即ち Schinz や Mercer によると Achondroplasia では, Dista 1 segment に比べ Proximal segment の短縮度が著し いのが, 特徵といわれるが（第 1 図の 2 及び 4 ）, 中

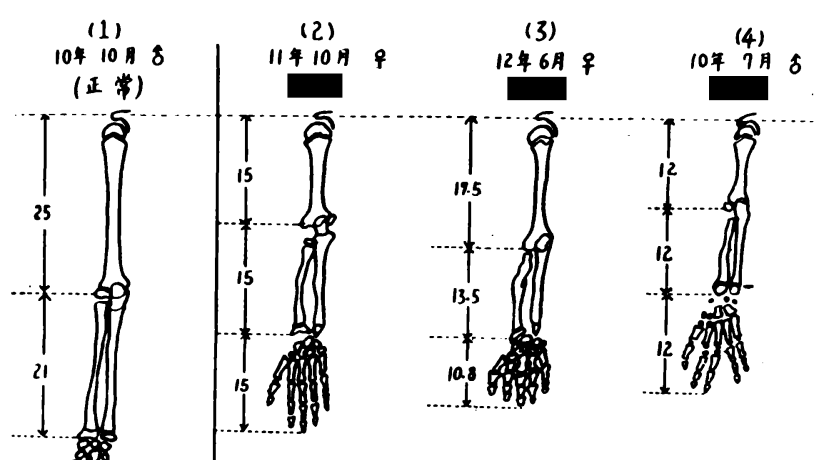

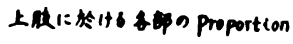

第 1 図
には末梢側に下る程短縮度が増強し. 手指骨が甚だ太 く短くなるあのあある.

2）第 3 指が橈側に，第 4 指が尺側に開排位を取る 変形 “Main en trident” は Achondroplasia の特徴 といわれるが，我々は之を 4 例に認めた。

3) 肘関節の最大伸展が $170^{\circ}$ から $140^{\circ}$ 程度に多少 とも制限されるものが 12 例中 8 例に認められた。

4) 卡肢の変形では 0 脚が多いが (5) 正常なもの ( 3 例)，X脚（2 例）あみられた.

5)血液化学的兹見は大半汸於て正常で, Alkaline phosphatase む2 例 (23.6 及び 24.4 ShinowaraJones-Reinhart Unit)を除き正常範囲にとどまつた.

6) 乙線像の多様性; Kaufmann の組織学的分類 之同様, 本症の示すレ線像も種々である. 典型的な

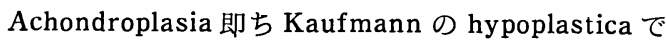
は典型的外観（頭が大きく, 鞍舅を主とする特有な顔, 定型的な非均衡性侏儒, 骨盤の水平位）を呈しながら, そのレ線所見は意外に少いあのがある，即ち長管骨が 太く短く「メタフィーゼ」の巾の増大, 寛骨臼蓋の水 平位等,骨のいわば形態的な軽い変化にとどまり,「エ ピフィーゼ」の質的変化に乏しく, 従つてレ線所見の みでは,「ヒョンドロ」と診断する事が困難な場 合さ えある．第 2 図は Achondroplasia の種々なレ線像の 「シェーマ」であるが,（1）脊椎, 股及び滕部は略々

(1)

(2)

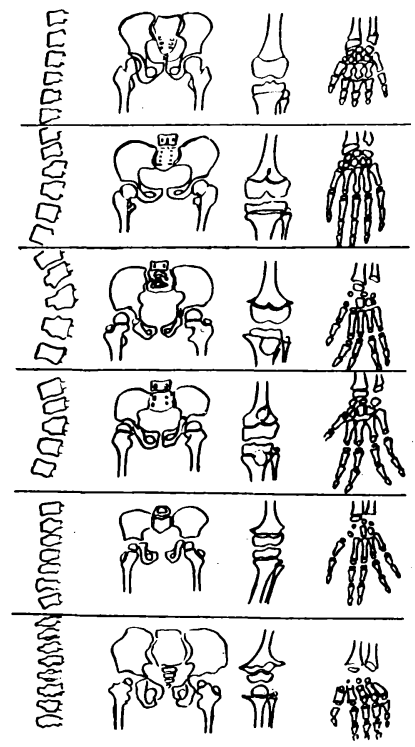

第 2 田 Achondroplasia 
正常で，四肢末端，即ち指趾が著しく太く短い（2） 逆に指趾は正常で骨盤, 股及び滕部では桓度の変化, 耠椎では胸腰椎境界部に Keilwirbel と Kyphose が ある. (3) 一 (5) は Classical Achondroplasia と も称すべき型. 脊柱では種々な程度の Keilwirbel と Kyphose がある,特有な「メタフィーゼ」の変化に扣 え, 手指の “Main en trident” が存在する. hyperplastica とも称すべき型でX脚があり，脊柱で は洲発性扁平椎の所見を呈し，其の他の骨変化も高度 で、 レ線的には Osteochondrodystrophy への移行を 示すが，躲幹に比し，四肢が著るしく短いという Achondroplasia の特徽具備している.

7) Osteochondrodystrophy は4例であるが，中 3 例は, Achondroplasia の臨床所見或はレ線像とも 相当に隔つて居り，といつて Morquio 病や Gargoylism の概念とも一致せず，更に検討を贸する症例 である. 他の 1 例は Gargoylism（5才. 仿）で発育 遅延が主訴である。現在起立は出来るが步行不能で， 体格は斗上型で首が短かく，独特の顔貌を星し，骨端 核はなほすべて未出現である.現在なほ発語不能で知 能障碍の存在を思わせる.

\section{Osteogenesis imperfecta 2 例}

8 才，及び 15 才の男児で夫々病的量折 10 回及び 5 回の既往歴があり，本症では Alkaline Phosphatase の著増（30.2 及び 20.0 Shinowara-Jones-Reinhart U.) が特徵である. 中 1 例に対しては Durabolin 療 法を試み体重增加之, 窒素, 燐, 「カルジウム」平衡 に改善をあたらしたが，骨のレ緗所見に変化を及ぼす までには至らなかつた。

\section{3. 所犕異型くる病に於ける骨变化}

先天性骨系統疶患の標題の下に，くる病を論ずるの は妥当と思われないが,くる病がとかく「ヒョンドロ」 と誤られ易い上に，最近では英国の Dent 等により難 治性くる病に先天性, 遺伝性因子の関与も指摘されて いるので，始で父艮及び姉妹の 2 組のくる病䍜患の経 験をのべる. 先づ最初は 31 才の父とその 3 才の娘の 1 組で, 父親は, 極度の両大腿内反, 在外反滕, 左内反 膝, 右外反, 左内反下腿という高度の下肢変形である が，上肢変形はなく，此の状態は遺伝性くる病として 報告したDent の症例に酷似している.（第 3 図a 及び b ） $3 才 の$ 才娘はくる病性 O脚で内反股を伴い Alkaline phosphatase は 18.0 Shinowara-Jones-Reinhart U. で中等度の増加を示す.

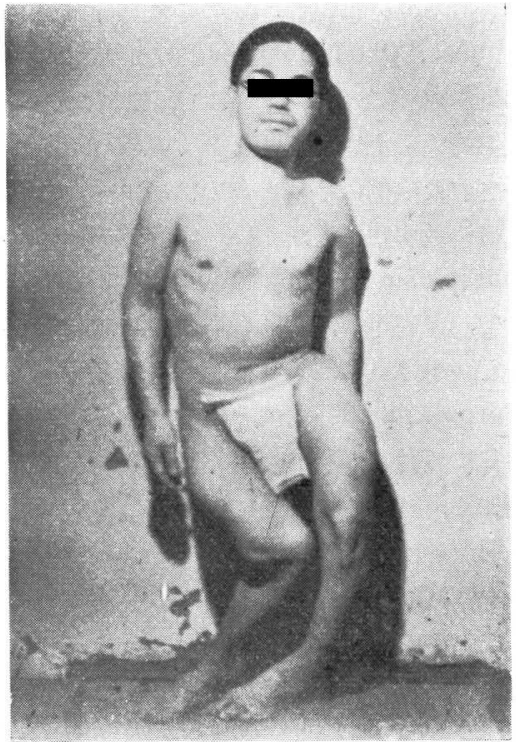

第 3 図a，31才令

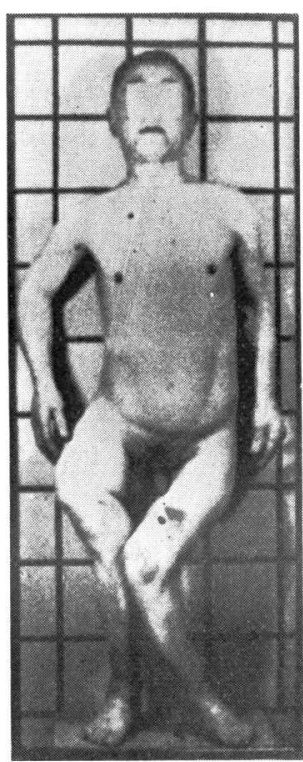

第3园b. Dent 0 症例
次は 18 才及び 14 才の虾 妹に発生したくる病の1組 で，峬の方は両下腿内反の みの変批であるが，炉は脊 柱の高度のKy phoskoliose 内反股，大腿内反，下腿内 反，上肢では内反村さいう 系統的変化を示した。

以上のくる病家族内発生 の経験は、例えば KashinBeck 氏病の様に，後天的 な家庭環境々いう因子によ つて, 同一疾病が家族的に 発生する事があり得るの で，直ちに先天的と断ずる わけには行かないが, 難治 性乃至異型くる病の或屯の は体質素質の遗伝に上つて 発生する可能性がある被を示唆する症例と我々は洘え ている.

\section{4.「アルカプトン」尿性骨関節症 4 例}

「アルカプトン」疗症は先天性遺伝性の蛋年中間代 謝晎常による甚だ稀な疾患で，其の学関節変化は壮年 期以後に現われ，就中脊椎椎間板の変性，消失によ 
り, 後天的に身長の短縮を来すので, 妘に侏懦症の一 原因疾患として述へる. 本症の代謝異常は必須「アミ ノ」酸である Tyrosin, Phenylanin 0中間代謝産物 上思われる「ホモゲンチジン」酸(以下「木酸) が蛋 白分解酵素障碍のため, 中間破壊が行われずにそのま ま尿中に排泄され，或は体内組織中に沈着するもので ある. 花北は第 7 回の本会に於て安部安和博士と共に 北九州に於ける 1 家系の 12 名について報告を行つた か，最近隱岐島の 1 患者を発見，現地調査により更に 2 名の本患者と, 既に死亡し本症と推定される 1 名計 4 例を得た。その臨床症状は（1）Ochronosis（2） Alcaptonuria (3)Osteoarthrosis deformans alcaptonuria で最後の骨関節症のみは 40〜j0 才以後, 腰 痛, 多発性関節痛を主訴として発生する. Ochronosis (組織褐色変性) は「木」酸が血流の比較的乏しい軟 骨, 腱, 靱帯その他に吸収されるための変性で, 皮膚 では耳介, 腰椎部, 膝部, 手指など突出部に著明に現 われる. Alcaptonuria は排尿後放置すると次第に尿 が黒変するもので，下着や「パンッ」などに黒いし がつき，之を主訴として来院するのが大半である，骨 関節症は壮年期以後に現われるが, 特に脊椎に著しく, 椎間板は殆んど消失する. 腰痛のため遂には歩行困難 となり, 身長は青年時に比べ, 第 1 例で $9 \mathrm{~cm}$, 第 2 例 で $13 \mathrm{~cm}$ も短縮している.

\section{5. 甲状腺性侏儒应 4 例}

内分泌性侏儒症は Willkins によると, (1， Hypothyroidism (2) Sexual precocity with early epiphyseal fusion (3), Hypopituitarism (4) Mixed types の 4 つに分類されているが，内分泌腺相互の関 係加ら考えて単一の腺の異常による病像として解釈す ることが困難な場合も多い。それにしても従来は大部 分が生長モルモン不足による下垂体性と診断され勝ち であつた。しかし最近甲状腺機能検査法の進歩により 下垂体性之診断されたものの中から，多分に甲状腺性 のものが分離される様になり，而も本症の特有なレ線 像之著明な治療效果から最近頓に内科及び整形外科医 の関心がたかまりつつある．我々の経験した甲状腺性 怢懦症は 4 例で, 其の一般臨床的事項及び検査所見は 第 $2 ， 3 ， 4$ 表の如く又第 1 例の治療成績は第 4 図の如 くである. 之を総括すると，

1）諸検査により明かな甲状腺機能低下があり，2） 而もその機能低下は TSH test によつても機能の増
第 2 表甲状腺性侏懦症（其の 1)

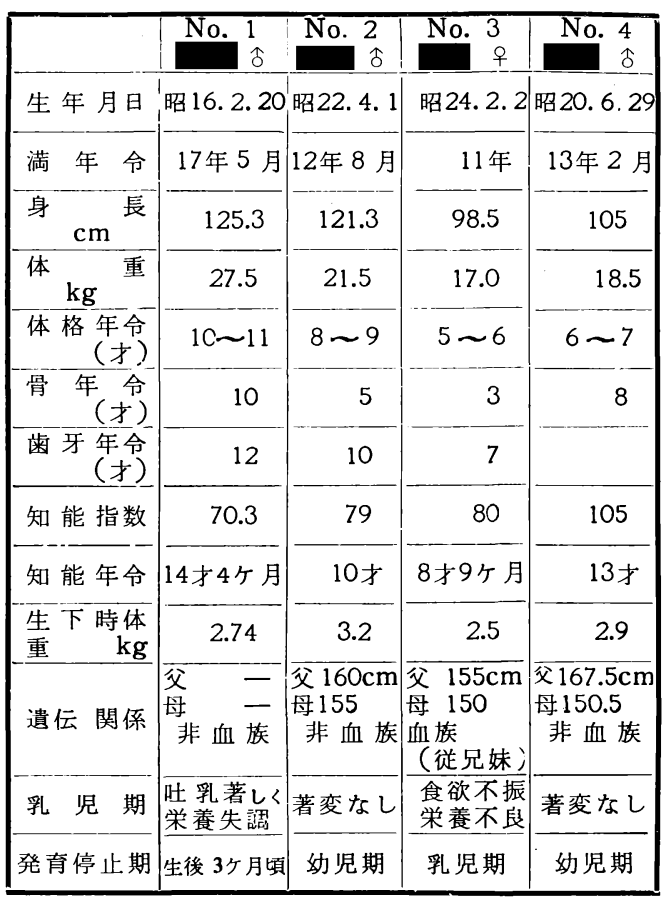

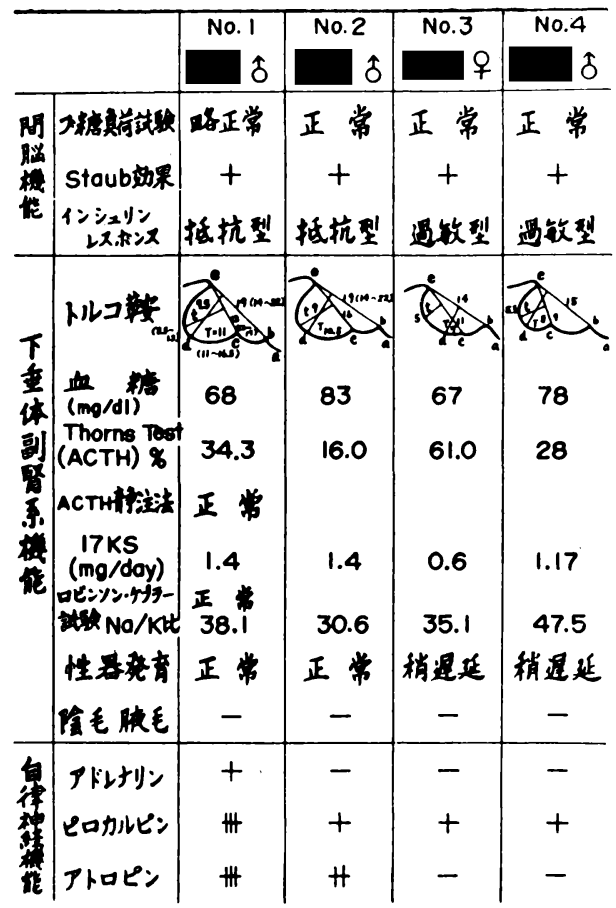

第 3 表 甲状腺性侏需症（其の 2) 


\begin{tabular}{|c|c|c|c|c|c|}
\hline & No.I & No.2 & No.3 & No.4 \\
\hline \multicolumn{6}{|c|}{$I^{131}$ 捉取率 50} \\
\hline \multirow{2}{*}{\multicolumn{6}{|c|}{ TSH テスト }} \\
\hline & & & & & \\
\hline \multirow{2}{*}{\multicolumn{2}{|c|}{ P.B.I $\quad r / d 1$}} & & & & \\
\hline & & 0.2 & 1.5 & 1.0 & 1.9 \\
\hline \multirow{2}{*}{\multicolumn{2}{|c|}{ 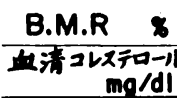 }} & -7.3 & -0.8 & -8 & -15 \\
\hline & & 208 & 212 & 261 & 265 \\
\hline \multirow{3}{*}{$\begin{array}{l}\text { 治 } \\
\text { 音 } \\
\text { 法 }\end{array}$} & \multirow{3}{*}{$\begin{array}{l}\text { 絭刺 } \\
\text { 一日量 } \\
\text { 期间 }\end{array}$} & チラーダン & チラーヂン & $\begin{array}{l}\text { チラーダン } \\
\text { ホせルE: }\end{array}$ & チラーヂン \\
\hline & & 0.06 & 0.02 & 0.03 & 0.04 \\
\hline & & 15个月 & 254月 & 14月 & 15个月 \\
\hline \multirow{5}{*}{ 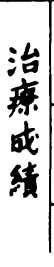 } & \multirow{2}{*}{\begin{tabular}{|l|} 
身 \\
長 \\
\end{tabular}} & 144.5 & 123.5 & 99 & 113 \\
\hline & & +18.9 & +2.2 & +0.5 & +8 \\
\hline & 体現在 & 39.5 & 26.5 & 17 & 21.0 \\
\hline & \begin{tabular}{l|l} 
& \pm \\
\end{tabular} & +13.5 & & \pm 0 & +2.5 \\
\hline & 影 果 & \# & & & + \\
\hline
\end{tabular}

第 4 表 甲状腺性侏需症（其の 3)
高を示さなかつた事から下垂体性の甲状腺機能低下で はなく，原発性機能低下である.3）第 1 例に見る如く 甲状腺末投与による著しい生長促進之基礎代謝の増加 があり, 殊に身長は既に年令的には生長停止期にあり ながら 15 ケ月間に $18.9 \mathrm{~cm}$ という大量の増加を来し た. 4) 骨変化の中, 一次的変化は一種の enchondrale Ossifikationsstőrung で,（i）骨端核出現の遅延, 不規則化，分節化（ii）骨端線閉鎻の遅延（iii）骨端 の骨化障碍によつて表わされる特有の変化で, 二次的 変化は，骨化障碍を基にして荷重関節たる股関節に特 有な負荷変形を来す Osteoarthropathia hypothyreotica あり, その軽度の変化が第 1 例にのみ, 内反股, 骨頭の扁平化といふ形で出現している.

之等の事実から 4 例の侏儒症の原因が原発性甲状腺 機能低下にある事は間違いなく，而もその機能低下の 原因は, 乳児期に於りる栄養障碍又は甲状腺の変性, 機能低下を来したもので，甲状腺の先天的欠損又は畸 型に基く Kretinismus とはやや性質を異にすると我 々は考えている. (引用交献略)

（西尾教授の御校閲に深謝し，また種々御協力を睗わ つた鳥取県立整肢学園, 池田正三園長, 高田允克博士 に謝意を表す.)

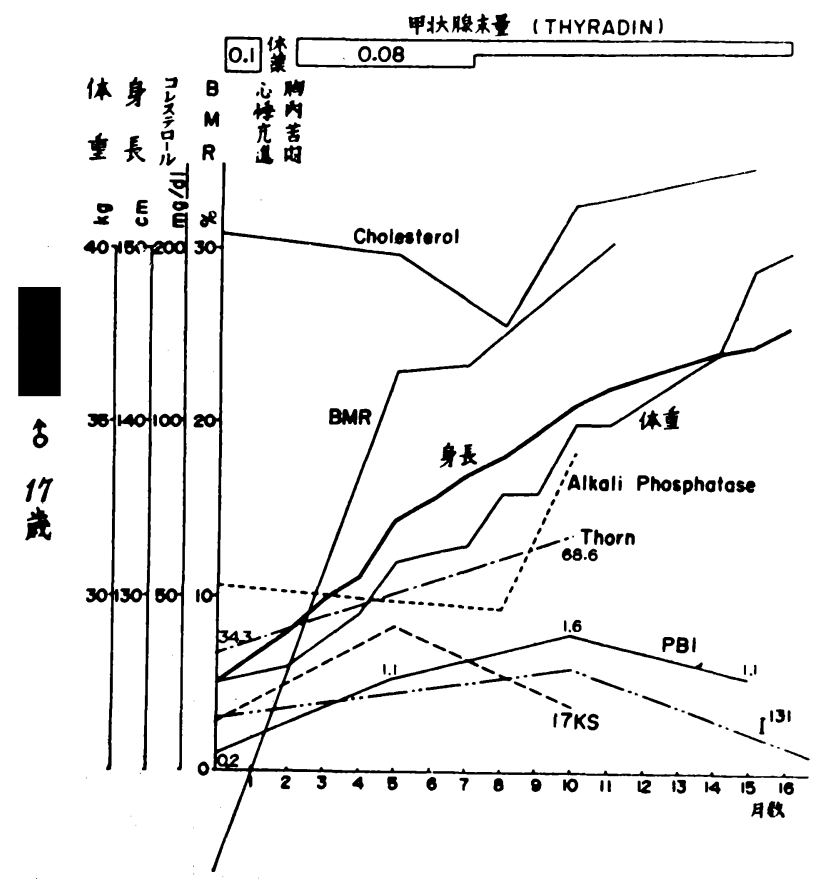

第 5 表 甲状腺末による侏儒症治療成績 